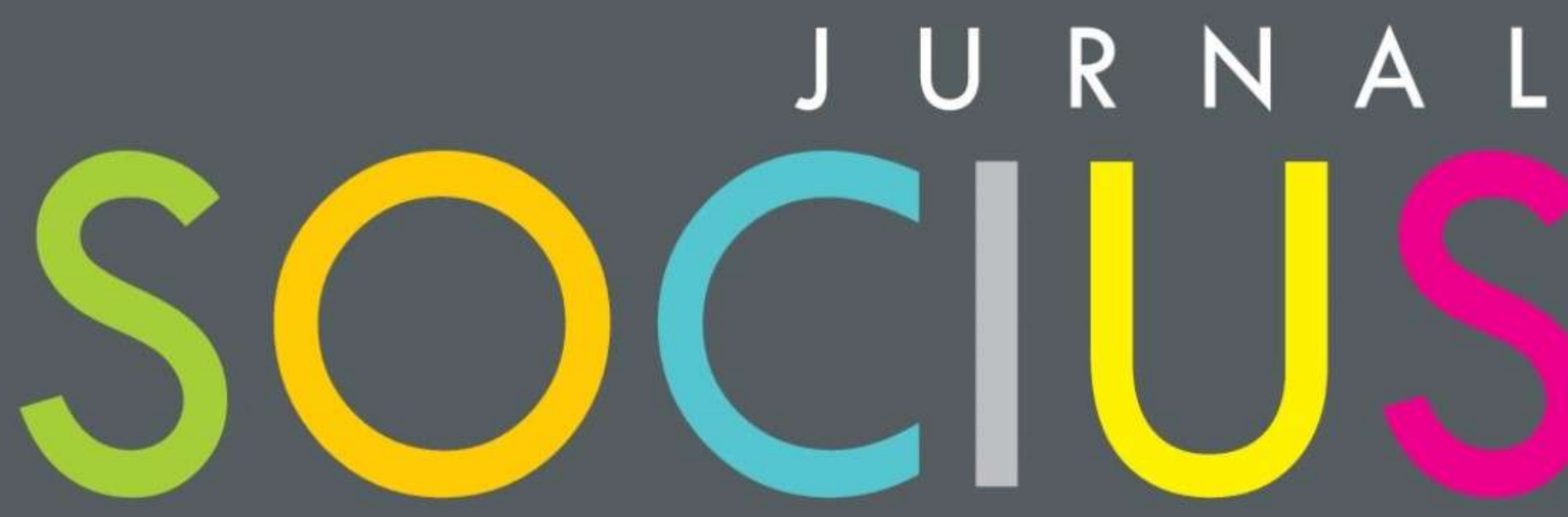

Journal of Sociology Research and Education

DITERBITKAN OLEH :

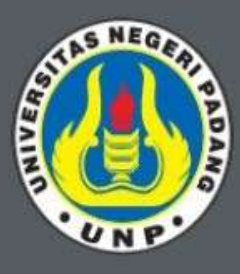

LABOR JURUSAN SOSIOLOGI FAKULTAS ILMU SOSIAL UNIVERSITAS NEGERI PADANG 


\section{SOCIUS}

Vol. 5, No.1, Th. 2018

ISSN : 2356-4180 (cetak)

2442-8663 (online)

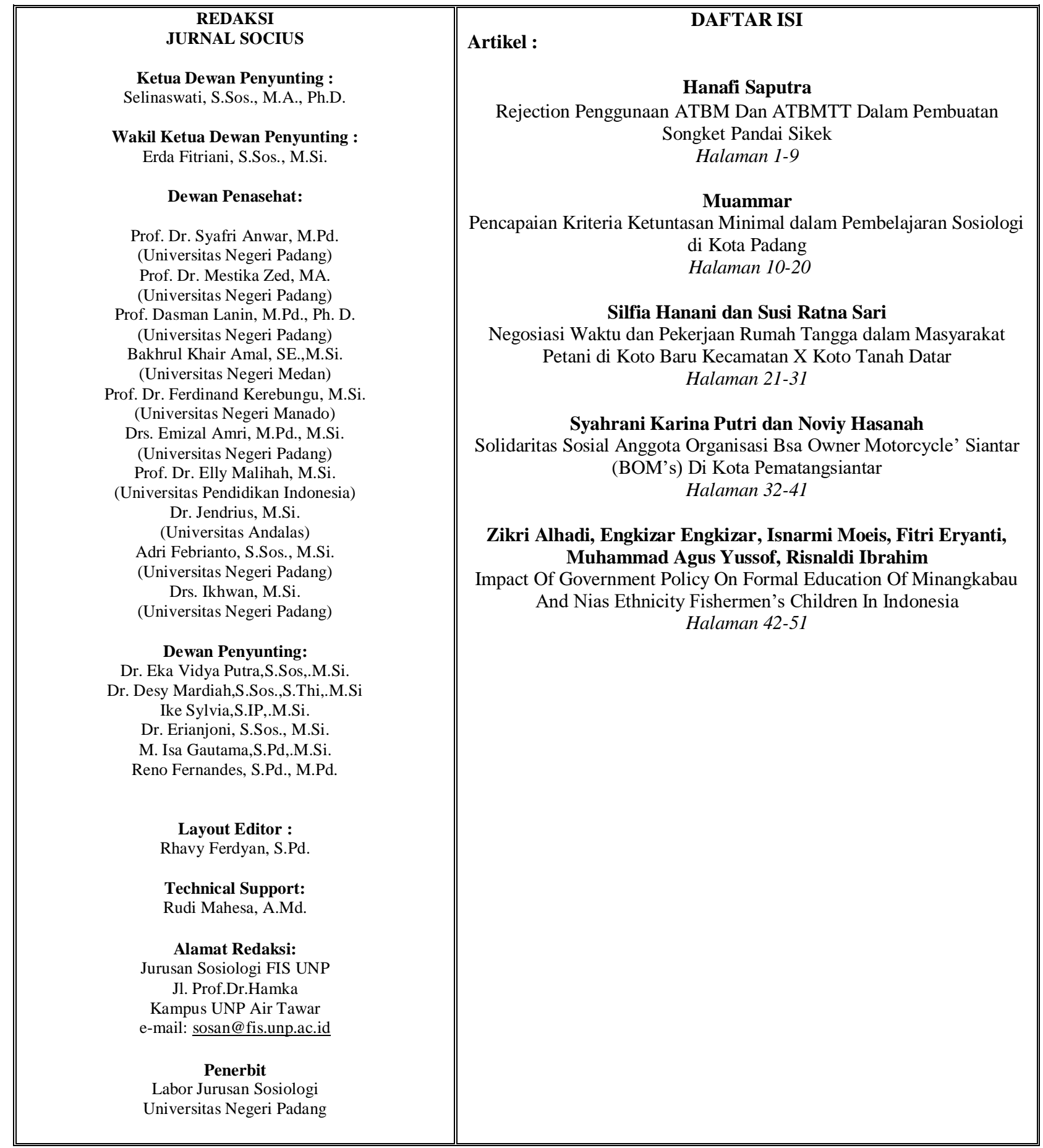




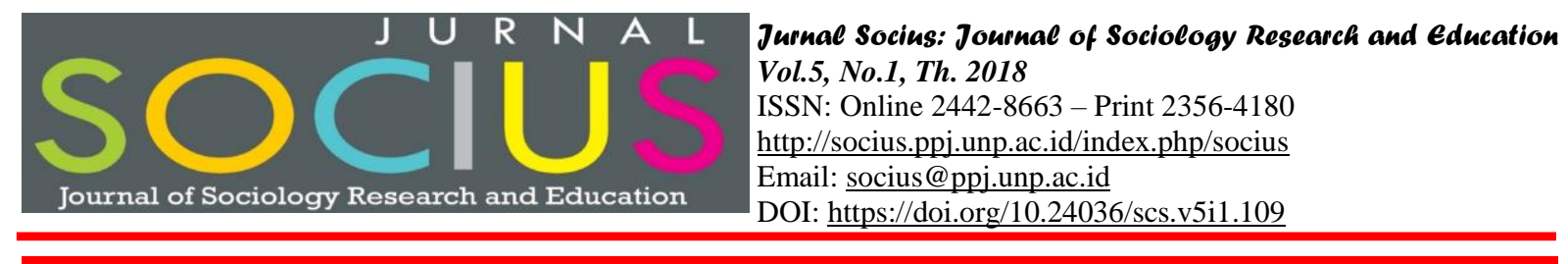

\title{
REJECTION PENGGUNAAN ATBM DAN ATBMTT DALAM PEMBUATAN SONGKET PANDAI SIKEK
}

\author{
Hanafi Saputra
}

Universitas Negeri Padang

email: saputra.hanafi25@gmail.com

\begin{abstract}
Abstrak
Pandai Sikek merupakan sentral produksi songket terkemuka di Sumatera Barat. Songket Pandai Sikek yang tergolong berkualitas tinggi tersebut dibuat menggunakan alat tenun tradisional yang dikenal dengan panta. Meskipun bisa menghasilkan songket yang berkualitas, namun panta memiliki keterbatasan-keterbatasan, antara lain: proses bertenun yang membutuhkan waktu lama, tingginya resiko kesalahan, dan sebagainya. Dihadapkan pada keterbatasan itu, Pemerintah Pusat melalui Departemen Perindustrian RI memperkenalkan alat tenun baru, yaitu ATBM, serta ATBMTT yang merupakan produk beberapa pengrajin (penenun) setempat. Hanya saja kedua peralatan baru itu (ATBM \& ATBMTT) ditolak kehadirannya oleh penenun setempat, buktinya lebih dari $98 \%$ penenun tetap menggunakan panta.Hasil penelitian menunjukan, bahwa penenun menolak (rejection) ATBM dan ATBMTT sebagai pengganti panta adalah sebagai berikut: (1) keterbatasan informasi tentang esensi ATBM \& ATBMTT sebagai alat inovasi; (2) tingginya kerumitan dan keterbatasan alat inovasi; (3) rendahnya kualitas produk ATBM dibandingkan produk panta sehingga harga jual produk rendah; (4) khusus ATBMTT, adanya hambatan agen pembaru (keengganannya untuk menyebarkan ATBMTT kepada penenun lain); dan, (5) adanya nilai sistem yang tertanam dalam diri adopter (penenun). Nilai sistem tersebut yaitu pemahaman tentang menenun merupakan keterampilan sakral dan identitas serta jati diri sebagai orang Pandai Sikek.
\end{abstract}

Kata Kunci: Rejection, ATBM, ATBMTT, Panta, dan Songket Pandai Sikek.

\section{Abstract}

Pandai Sikek is the leading center production of songket in West Sumatera. Songket Pandai Sikek which is categorized as high quality is made using traditional looms known as panta. Although it can produce a quality songket, but the panta has limitations, among others: the process of weaving that takes a long time, the high risk of error, and so forth. Dealing with this limitation, the Central Government through the Ministry of Industry introduced a new loom, ATBM, and ATBMTT which is the product of several local craftsmen (weavers). It's just that both new equipment (ATBM \& ATBMTT) denied presence by the local weavers, the proof is more than $98 \%$ of weavers still use the panta. The results showed that the rejection of ATBM and ATBMTT rejection as a substitute for panta were as follows: (1) limited information about the essence of ATBM \& ATBMTT as an innovation tool; (2) the high complexity and limitations of innovation tools; (3) low quality of ATBM product compared to pag product so low product selling price; (4) special ATBMTT, the presence of barriers of the renewal agent (reluctance to spread ATBMTT to other weavers); And, (5) the value of the embedded system in the adopter (weavers). The value of the system is the understanding of weaving is a sacred skill, identity and personality as a person Pandai Sikek.

Key Words: Rejection, ATBM, ATBMTT, Panta, and Songket Pandai Sikek.

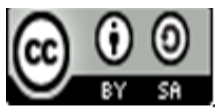

Received: March 18, 2018 Revised: April 4, 2018 Available Online: June 18, 2018

Jurnal Socins: Journal of Sociology Research and Education Vol. 5, No.1, Th. 2018

ISSN: Online 2442-8663 - Print 2356-4180

Copyright $\odot 2018$, Jurnal Socius 


\section{Pendahuluan}

Pandai Sikek merupakan salah satu nagari penghasil songket terkenal di Sumatera Barat, bahkan di Indonesia. Dalam menghasilkan songket, penenun Pandai Sikek sejak dahulu menggunakan alat tenun yang bernama panta. Alat itu digunakan secara manual, termasuk dalam proses pembuatan motif yang dikenal dengan sistem bacukie (dicongkel). Dengan proses menenun secara manual ini, untuk menghasilkan sepasang songket (kodek ukuran $100 \mathrm{~cm} \mathrm{x}$ $160 \mathrm{~cm}$ dan salendang ukuran $50 \mathrm{~cm}$ x $180 \mathrm{~cm}$ ) dibutuhkan waktu hingga 45 hari kerja (dengan durasi waktu 8 jam/ hari). Selain itu, proses menenun secara manual juga memiliki resiko kesalahan yang cukup tinggi, seperti kesalahan dalam menenunkan motif.

Untuk meningkatkan keefektifan dan keefisiensian proses menenun, Ibu Mufidah Jusuf Kalla bersama pemerintah mendirikan Pusat Inovasi Tenun Pandai Sikek pada tahun 2008, terletak di Jorong Koto Tinggi Pandai Sikek. Beliau memberikan bantuan 5 unit Alat Tenun Bukan Mesin (ATBM) yang terdiri dari 4 unit ATBM jackart dan 1 unit ATBM dobby. Alat itu dipakai dengan menggunakan sistem kartu dalam pembuatan motif, dan sudah menggunakan tenaga listrik, serta sistem komputer.

Bantuan tersebut dilatarbelakangi oleh keinginan Ibu Mufidah Jusuf Kalla untuk meningkatkan kualitas dan juga kuantitas tenun Pandai Sikek. Keinginan tersebut muncul pasca kunjungan Wakil Presiden RI (pada masa itu Bapak Jusuf Kalla) beserta rombongan ke Pandai Sikek, setelah daerah ini (Sumbar) diguncang gempa pada tanggal 6 Maret 2007.

Sebagai alat baru, ATBM telah disosialisasikan melalui pelatihan kepada 150 penenun Pandai Sikek. ATBM mampu menghasilkan tenunan yang berukuran $180 \mathrm{~cm} \mathrm{x} 700 \mathrm{~cm}$ dalam waktu satu hari kerja ( 8 jam/ hari). Dengan sistem kartu yang dimilikinya, tingkat kesalahan menenun dengan alat itu mampu meminimalisir resiko kesalahan. Walau demikian, setelah pelatihan selesai, ATBM tidak digunakan oleh penenun Pandai Sikek. Kini, ke-5 unit alat itu hanya disimpan disalah satu ruangan Pusat Inovasi Tenun Pandai Sikek.

Pada tahun 2011, muncul ATBMTT yang dikembangkan oleh ide warga setempat, yaitu: Syafri; Suhandi; dan Afrizal.Alat tersebut merupakan panta dengan sistem pengerjaan menggunakan sistem kartu seperti ATBM. Alat itu memiliki keunggulan dibanding panta, karena sistem kartu yang dimilikinya. ATBMTT mampu menghasilkan songeket kodek ukuran $100 \mathrm{~cm}$ x $160 \mathrm{~cm}$ dalam waktu 7 hari kerja (8 jam/hari). Walau demikian, ATBMTT juga ditolak oleh para penenun.Hanya 30 dari 835 orang penenun Pandai Sikek yang menggunakan ATBMTT. Sementara, penenun lainnya tetap menggunakan panta. Hal itu menarik untuk diteliti, sehingga penelitian ini memfokuskan pada kajian proses penyebaran inovasi ATBM dan ATBMTT sebagai alternatif pengganti panta di Nagari Pandai Sikek.

\section{Metode Penelitian}

Penelitian ini dilakukan di Nagari Pandai Sikek Kecamatan X Koto Kabupaten Tanah Datar. Penelitian ini termasuk pada pendekatan kualitatif. Peneliti memilih pendekatan ini karena iamember peluang untuk mendapatkan informasi yang detail (lisan, tulisan, dan pengamatan) tentang pokok persoalan yang diteliti. ${ }^{1}$ Dengan kata lain, melalui pendekatan ini peneliti dapat memperoleh inofrmasi secara mendalam. Dilihat dari segi jenisnya, penelitian ini termasuk studi kasus intrinsik. ${ }^{2}$ Informan penelitian dipilih secara sengaja (purposive sampling), dengan jumlah informan 30 orang.

\footnotetext{
${ }^{1}$ John W. Creswel. 2003. Research Design.Pendekatan Kualitatif dan Kuantitatif. Jakarta: KIK Press Hal. 1.

${ }^{2}$ Sitorus, Felik. 1998. Penelitian Kualitatif Suatu Pengenalan. Bogor: IPB Hal. 2.
} 
Data dalam penelitian ini dikumpulkan melalui teknik observasi, wawancara mendalam (in-depth interview), dan studi dokumen. Agar data yang diperoleh lebih valid, maka dalam penelitian ini dilakukan triangulasi data. Dari data penelitian yang telah dikumpulkan, maka kemudian peneliti menggunakan teknik analisis data sebagai mana yang dikembangkan oleh Metthew B. Miles dan A. Michael Huberman. Kegiatan pengumpulan data (data collection) dalam model ini meliputi tiga komponen pokok, yaitu: reduksi data (reduction data); display data (display data); dan penarikan kesimpulan/ verifikasi (conclution/verifiying data). Ketiga kegiatan ini dilakukan secara terus-menerus selama berlangsung proses pengumpulan data lapangan. ${ }^{3}$

\section{Rejection ATBM dan ATBMTT}

ATBM merupakan alat tenun yang diperkenalkan oleh Pemerintah di Pandai Sikek sebagai alat tenun inovasi pengganti panta. Dalam proses pengenalan telah dilakukan pelatihan kepada penenun setempat, namun setelah pelatihan selesai alat tersebut tidak digunakan oleh penenun. Berkat adanya pelatihan tersebut, tiga orang peserta pelatihan (Safri, Suhandi, dan Afrizal) terinspirasi dengan sistem kerja ATBM. Bermodalkan pengetahuan dari pelatihan tersebut, muncul alat tenun inovasi baru yaitu ATBMTT yang merupakan panta dengan sistem kartu seperti ATBM.

Penolakan penenun dan elit pemerintah nagari Pandai Sikek terhadap alat inovasi ATBM atau pun ATBMTT dipengaruhi oleh faktor teknis yang terdiri dari kegagalan transfer of knowledge, tingginya tingkat kerumitan dan keterbatasan alat inovasi, serta rendahnya kualitas produk ATBM dibandingkan alat panta sehingga berdampak pada harga jualnya. Khusus ATBMTT, tidak meluasnya penggunaan alat tersebut disebabkan oleh hambatan dari agen pembaru. Hambatan itu berupa keengganan agen pembaru untuk menyebar luaskan pengetahuannya kepada penenun lain di Pandai Sikek, hal tersebut berhubungan dengan maindset tradisionalisme yang dimilikinya.

Selain faktor teknis, penyebab ditolaknya ATBM atau pun ATBMTT yaitu disebabkan faktor sosial budaya. Faktor ini berkaitan erat dengan nilai norma yang dianut masyarakat setempat dalam melihat songket. Songket bagi masyarakat setempat bukan sekedar benda yang bernilai ekonomi tinggi. Jauh dari itu, songket bagi mereka merupakan kekayaan, identity culture, dan jati diri sebagai orang Pandai Sikek. Selain itu, keterampilan menenun merupakan keterampilan yang mengandung unsur sakralitas. Dikatakan demikian, keterampilan menenun tidak dapat diajarkan kepada sembarang orang. Keterampilan menenun hanya boleh diajarkan kepada orang Pandai Sikek saja, yaitu urang saparuik. Mereka yang mengajarkan keterampilan kepada bukan orang Pandai Sikek, maka akan mendapatkan sangsi sosial dan juga sangsi moral.

Untuk menjelaskan hal tersebut, pada tulisan ini dibagi menjadi tiga pembahasan, yaitu: (1) rejection penggunaan Alat Tenun Bukan Mesin (ATBM), yang terdiri dari sub-bagian (a) keterbatasan informasi, (b) kerumitan dan keterbatasan ATBM, dan (c) rendahnya kualitas dan harga produk ATBM; (2) rejection penggunaan Alat Tenun Bukan Mesin Tapi Tradisional (ATBMTT), yang terdiri dari sub-bagian (a) hambatan dari penemu ATBMTT, dan (b) kerumitan dan keterbatasan ATBMTT; serta (3) songket sebagai identitas budaya, yang terdiri dari sub-bagian (a) menenun merupakan keterampilan sakral, dan (b) jati diri orang Pandai Sikek.

\footnotetext{
${ }^{3}$ Metthew B. Miles and A. Michael Huberman. 1984. Qualitatif Data Analisis. Bavarly Hills London New Delhi: Sage Publication.
}

Jurnal Socius: Journal of Sociology Research and Education Vol. 5, No.1, Th. 2018 


\section{Rejection Penggunaan Alat Tenun Bukan Mesin (ATBM)}

\section{Keterbatasan Inoformasi}

Sebagai alat inovasi, telah dilakukan sosialisasi kepada 150 penenun Pandai Sikek mengenai keberadaan ATBM di nagari tersebut. Dalam proses pengenalan inovasi itu, diketahui bahwa penenun tidak memiliki peluang yang bebas untuk mendaftarkan diri menjadi peserta sosialisasi, sebab proses sosialisasi yang dilakukan tidak disebarkan melalui papan pengumuman Nagari atau pun Jorong. Dengan demikian, penenun mengalami keterbatasan informasi tentang pelaksanaan sosialisasi tersebut, sehingga banyak penenun mengaku tidak memperoleh informasi yang jelas mengenai sosialisasi keberadaan alat ATBM.

Peserta dalam pelatihan itu langsung ditetapkan oleh Pemerintah Nagari khususnya oleh Kasi Ekonomi bersama dengan Wali Jorong setempat. Sehingga, tidak menutup kemungkinan kasus nepotisme terjadi. Mereka yang memiliki kedekatan yang lebih dengan Wali Jorong atau pun Pemerintah Nagari akan menjadi prioritas utama (mendapatkan kesempatan lebih), seperti keluarga, karib kerabat,tetangga, dan teman dibandingkan dengan mereka yang tidak memiliki kedekatan demikian.

Dalam pelaksanaan sosialisasi, materi terdiri dari 3 macam yaitu: (1) materi mengenai alat ATBM, terdiri dari pengenalan alat ATBM dobby dan jackart, teknologi percepatan proses tenun songket, pengelosan, penghanian, serta penyambungan benang lungsi; (2) materi disain motif, terdiri dari pengembangan disain dan motif songket; serta (3) materi mengenai pencelupan benang, terdiri dari pengenalan alat dan bahan yang dibutuhkan, proses pencelupan benang termasuk di dalamnya takaran penggunaan zat pewarna, serta pengelolaan air limbah. Masing-masing materi diajarkan selama 6 hari, dengan pesertanya masing-masingn berjumlah 50 orang dan setiap materi memiliki peserta yang berbeda.

Peserta pelatihan memperoleh pengetahuan dan pengalaman yang terbatas, sesuai dengan materi yang diikutinya. Mengingat menenun bagi Penenun Pandai Sikek pada dasarnya merupakan keterampilan yang bersifat utuh, dengan adanya keterbatasan itu, maka keutuhan tersebut tidak diperolehnya. Dengan pembagian dan keterbatasan pengetahuan itu akan berujung pada pengotakan keterampilan, serta berdampak pada munculnya pembagian kerja. Dengan demikian, songket yang merupakan keterampilan yang bersifat holistic (menyeluruh) akan berubah menjadi keterampilan bersifat terbatas (unholistik).

Dalam pelaksanaan sosialisasi, instrutur didatangkan dari Majalaya. Pelatihan dilakukan menggunakan bahasa teknis dari daerah tersebut, sehingga penenun mengalami kesulitan untuk mengerti, mengingat adanya perbedaan bahasa teknis antar dua daerah tersebut. Hal itu juga ditambah dengan tidak adanya instruktur pendamping yang mengerti tentang ATBM dan mampu mempermudah proses transormasi informasi kepada peserta.

\section{Kerumitan dan Keterbatasan ATBM}

ATBM merupakan alat tenun yang terbuat dari bahan utama besi baja dan kayu. Pemerintah mendatangkan dua macam alat ATBM yaitu ATBM dobby dengan ukuran tinggi 3 meter, panjang 2,5 meter, dan lebar 2 meter, serta ATBM jackart dengan ukuran ukuran tinggi 2 meter, panjang 2,5 meter, dan lebar 2 meter. ATBM memiliki ukuran yang lebih besar jika dibandingkan dengan panta yang hanya memiliki ukuran tinggi 1,5 meter, panjang 2 meter, dan lebar 1,8 meter. ATBM dobby dan jackart didatangkan dengan jumlah 5 unit, dengan masing-masingnya ATBM dobby 1 unit dan jackart 4 unit. Selain itu, alat ATBM memiliki element-element yang lebih rumit dibandingkan alat panta.

Alat ATBM merupakan alat yang bersifat permanen, berbeda halnya dengan panta yang lebih bersifat fleksibel. Dengan demikian, dibutuhkan tempat khusus untuk ATBM. Dalam 
pembuatan motif, ATBM telang menggunakan sistem kartu yang dibuat menggunakan applikasi komputer. Kondisi tersebut turut mempengaruhi pilihan adopter untuk meengadopsi atau tidak. Faktor kemampuan yang dimiliki adopter diantaranya tingkat pendidikan serta keterampilan kompter yang terbatas, mengakibatkan adopter enggan menggunakan ATBM dan lebih memilih tetap bertahan menenun menggunakan panta.

\section{Rendahnya Kualitas dan Harga Produk ATBM}

Songket Pandai Sikek merupakan kain tenun khas yang terbuat dari benang bernuansa emas. Mereka menenun songket untuk dijadikan kodek, salendang, sisampiang, tangkuluak, salempang, cawek, dan saluakdalam acara-acara adat.Dalam satu kain songket, terdapat lebih dari lima jenis motif, ada motif yang digunakan untuk bagian tepi, bagian kepala kain, bagian badan kain dan bagian batas antar motif. Setiap motif yang dibuat penenun memiliki nilai-nilai dan unsur makna filosofi di dalamnya.

Songket Pandai Sikek memiliki ketentuan ukuran-ukuran yang digunakan oleh penenun sejak dahulunya. Ukuran tersebut dikenal dengan istilah halaian (helaian). Satu helai kodek songket Pandai Sikek memiliki ukuran $160 \mathrm{~cm}$ x $100 \mathrm{~cm}$, sedangkan salendang memiliki ukuran $160 \mathrm{~cm}$ x $30 \mathrm{~cm}$ serta $180 \mathrm{~cm}$ x $50 \mathrm{~cm}$. Sepasang songket Pandai Sikek memiliki harga minimal Rp. 3.500.000,-, bahkan pada tahun 2008 tercatat paling tinggi RP. 350.000.000,-.Songket produk panta memiliki hasil tenunan benang yang rapat/ padat, proses penyimpanan dengan cara digulung, tidak bisa dicuci dengan cara direndam menggunakan air atau pun deterjen.

Songket dengan ketentuan di atas dapat diperoleh penenun jika menenun menggunakan panta. Sementara, ATBM yang terdiri dari ATBM dobby dan ATBM jackart tidak mampu menghasilkan produk tenunan layaknya panta.Alat itu tidak mampu menghasilkan produk dengan motif yang lebih banyak dalam satu tenunan layaknya panta, dan tidak mampu menghasilkan motif yang lazim di Pandai Sikek. Motif yang dihasilkannya memiliki ukuran yang berbeda. Dengan demikian nilai fiolosofi yang terdapat dalam motif songket Pandai Sikek menjadi hilang.

Penyebab tidak digunakan ATBM oleh penenun khususnya peserta pelatihan yaitu chost benefite berupa pertimbangan kualitas dan harga jual dari produk ATBM itu sendiri yang jauh dari harapan masyarakat. Produk yang tidak mampu menghasilkan kain songket khas Pandai Sikek menyebabkan penenun lebih memilih tetap menenun menggunakan panta. Selain harga jual yang rendah, esensi terkait nilai dan makna filosofi dari motif songket tidak mampu dihasilkan dengan ATBM. Padahal, selain untuk nilai ekonomi, songket bagi masyarakat Pandai Sikek juga merupakan identidas dan jati diri serta kebanggaan mereka.

\section{Rejection Penggunaan Alat Tenun Bukan Mesin Tapi Tradisional (ATBMTT)}

Selang tiga tahun setelah keberadaan ATBM tepatnya bulan Oktober 2011 muncul alat tenun inovasi baru yang dipelopori oleh Syafri, Suhandi, dan Afrizal, bernama Alat Tenun Bukan Mesin Tapi Tradisional. Pelopor atau agen pembaru dulunya merupakan peserta pelatihan ATBM. Mereka tertarik dengan sistem kartu yang dimiliki ATBM. Bermodalkan pengetahuan saat pelatihan, mereka memanipulasi alat panta dengan pembuatan motif menggunakan sistem kartu. Dengan demikian munculah ATBMTT, namun dalam perkembangannya ATBMTT hanya digunakan oleh 30 penenun dari 835 orang penenun yang ada di Pandai Sikek. Sementara, penenun lainnya tetap bertahan menggunakan panta. kondisi tersebut ternyata disebabkan oleh:

\section{Hambatan Dari Penemu ATBMTT}

Keberadaan ATBMTT sebagai alat inovasi baru tidak diikuti dengan pelaksanaan sosialisasi (pelatihan) mengenai alat itu. Pengenalannya hanya melalui informasi dari orang ke

Jurnal Socius: Journal of Sociology Research and Education Vol. 5, No.1, Th. 2018 
orang.Dengan demikian, mereka yang berada di sekitar penemu sajalah yang mengetahuinya. Sementara, mayoritas penenun Pandai Sikek yang lain tidak mengetahui secara jelas tentang alat tersebut. Informasi keberadaan ATBMTT yang tidak tersebar secara meluas kepada penenun Pandai Sikek, ternyata juga disebabkan oleh penemunya yang enggan untuk berbagi ilmu kepada penenun lain.

Bagi penenun yang berminat menggunakan ATBMTT, alat tersebut dapat diperoleh dengan membeli seharga Rp. 10.000.000,- sampai Rp. 15.000.000,-- Sementara, bagi penenun yang tidak mampu membelinya, dapat bekerja dibawah sistem yang ditetapkan agen pembaru. Walau demikian, dari diri penemu sendiri mereka enggan untuk menjual kepada penenun lain. Kenyataan tersebut didasari oleh ketakutan penemu terhadap ancaman bagi perekonomian mereka. Jika ATBMTT dimiliki oleh mayoritas penenun, maka jumlah songket akan banyak, dengan demikian akibatnya proses pemasaran lebih susah serta harga songket menjadi jatuh (rendah).

Penemu sebagai agen pembaru menjalankan perannya sebagai penghambat adopter mengadopsi inovasi yang diketahui dari strategi-strategi yang diciptakannya bertujuan agar penenun tidak bisa memiliki secara pribadi ATBMTT. Kemudian, pola pikir mereka yang tradisionalisme, sehingga agen pembaru takut memperoleh kerugian karena dapat mempengaruhi perekonomiannya.

\section{Kerumitan dan Keterbatasan ATBMTT}

ATBMTT merupakan alat tenun terbuat dari bahan dasar kayu yang pada dasarnya merupakan alat tenun panta dengan mengimplementasikan sistem kartu dari alat ATBM. ATBMTT memiliki ukuran tinggi 1,5 meter, panjang 2 meter, dan lebar 1,8 meter. Sama halnya dengan ATBM, ATBMTT juga merupakan alat tenun yang bersifat permanen. ATBMTT yang telah terpasang tidak dapat dibongkar kembali, jika hal itu terjadi, maka ketika merakitnya akan sama halnya dengan proses pembuatan ATBMTT dari semula. Dengan kondisi alat yang permanen, maka dalam pengoperasian ATBMTT dibutuhkan tempat khusus. Selain itu, keterbatasan kartu motif yang belum tersedia untuk semua motif songket Pandai Sikek. Keterbatasan itu karena pembuatan kartu motif membutuhkan waktu yang lama dan dipengaruhi oleh minimnya tenaga ahli yang mampu untuk membuatnya. ATBMTT juga merupakan alat tenun dengan tingkat kerumitan yang tinggi dibandingkan panta. Kerumitannya tersebut terletak pada sistem kerja kartu motif, kemudian dari banyaknya rajutan benang yang tersambung kepada benang pakan. Jika terjadi kendala maka dibutuhkan tenaga terampil untuk mengatasinya.

\section{Songket Sebagai Identitas Budaya}

\section{Menenun merupakan keterampilan sakral}

Keterampilan menenun diyakini masyarakat setempat diperoleh oleh nenek moyang mereka dengan pasumpahan (perjanjian). Perjanjian tersebut berupa larangan mengajarkan kepada bukan orang Pandai Sikek. Apabila itu dilanggar maka pelaku akan memperoleh sangsi moral dan sangsi sosial. Hal tersebut masih dipercaya oleh masyarakat setempat dan dalam proses transformasi keterampilan perjanjian itu juga diregenerasikan. Selain itu, dikatakan keterampilan sakral karena dalam proses trasformasi keterampilan tersebut melalui aturan, ketentuan, tata cara dan upacara tertentu. Proses belajar menenun tidak dapat dilakukan tanpa upacara tersebut.

Dengan demikian, penolakan dipengaruhi oleh motivasi dalam diri serta pengaruh nilai yang dianut. Keterampilan menenun merupakan keterampilan yang mengandung nilai sakral. Keterampilan itu tidak dapat diajarka kepada orang yang bukan saparuik (memiliki garis keturunan ibu). Hal itu hanya dapat dilakukan jika menenun dilakukan menggunakan panta. 
Sementara, jika menenun dilakukan menggunakan alat ATBM atau pun ATBMTT hal tersebut tidak dapat dilaksanakan, dengan kata lain nilai kesakralan dalam proses regenerasi atau pun trasformasi keterampilan tersebut akan hilang.

\section{Jati Diri Orang Pandai Sikek}

Kerajinan tenun songket di Pandai Sikek tidak dapat dipisahkan dari kehidupan perempuan Pandai Sikek itu sendiri. Perempuan Pandai Sikek dituntut harus pandai menenun, jika tidak pandai menenun, maka bukan perempuan Pandai Sikek. Hal itu tidak terlepas dari falsafahKato nan ampek (kata yang empat) dalam kehidupan sehari-hari orang Pandai Sikek. Keterampilan menenun akan mengajarkan nilai-nilai positif kepada penenunya. Nilai tersebut diantaranya nilai ketekunan, nilai kesabaran, nilai ketelitian, nilai kreatifitas, dan nilai kebersamaan. Mereka meyakini nilai tersebut dapat diperoleh jika mereka menenun menggunakan panta.

Selain kewajiban untuk memiliki keterampilan menenun, songket Pandai Sikek juga merupakan benda wajib yang sakral serta benda fundamental dalam setiap perhelatan serta prosesiadat. Songket merupakan salah satu pakaian kebesaran, diantaranyaoleh pangulu, bundo kanduang, dubalangyang digunakan pada kegiatan-kegiatan adat. Fungsinya sebagai baju gadang, baju kurung, kodek, saluak, sisampiang, cawek, tangkuluak, dan sebagainya.Selain itu, songket Pandai Sikek merupakanbenda wajib yangdigunakan dalam proses adat seperti perkawinan, pengangkatan pangulu,batagak rumah, turun mandi, proses penguburan jenazah, dan proses penyelesaian pelanggaran adat. Penggunaan songket pada prosesi tersebut juga diikuti dengan aturan-aturan dalam penggunaannya, seperti ketentuan mengenai jenis, tipe, dan fungsi dari kain songet tersebut. Contohnya, dalam prosesi timbang tando harus menggunakan songket untuak tingkuluak atau salendang. Alasan penggunaan tersebut dilatarbelakangi oleh kepercayaan bahwa prosesi timbang tando merupakan prosesi yang suci dan sakral. Songket yang digunakan pada tubuh bagian atas juga dianggap lebih berharga, maka sesuatu yang samasama berharga lebih tepat untuk disatukan.

Songket bagi orang Pandai Sikek bukan lah sebatas benda yang bernilai ekonomi, akan tetapi songeket merupakan kekayaan serta identitas dan juga kearifan lokal yang mereka miliki. Nilai sakralitas yang diyakini masyarakat setempat tersebut juga berpengaruhi pilihan adopter untuk tidak mengadopsi alat inovasi yang ada. Mereka meyakini nilai sistem itu hanya dapat diperoleh apabila mereka menenun menggunakan panta. Sementara, jika mereka menenun tidak menggunakan panta maka nilai-nilai tersebut (khususnya nilai sakralitas) akan hilang, sebab unsur filosofi tidak dimiliki produk selain panta.

Kemudian, ada ancaman dari luar terhadap songket Pandai Sikek. Tantangan serta ancaman yang datang dari luar mereka membuat nilai sistem menjadi lebih terintegrasi dalam dirinya. Adopter memilih mempertahankan menenun menggunakan panta ketimbang ATBM atau pun ATBMTT, untuk mempertahankan identitas dan jati diri sebagai orang Pandai Sikek. Kemudian, demi melestarikan benda handmade, antik, sakral, dan fundamental yang hanya dapat diperoleh penenun melalui proses menenun (tradisional) menggunakan panta.

\section{Penutup}

Pertama, rejection penggunaan ATBM. Terdapat beberapa penyebab penenun tidak menggunakan ATBM sebagai alat tenun pengganti panta. Penyebab tersebut tidak terlepas dari proses difusi yang terjadi serta kondisi dari alat ATBM itu sendiri. Dari hasil penelitian penyebab penenun tidak mengadopsi ATBM karena: (1) keterbatasan informasi, (2) kerumitan dan keterbatasan ATBM, serta (3) rendahnya kualitas produk ATBM. 
Kedua, rejection penggunaan ATBMTT. Penolakan penenun menggunakan alat ATBMTT ini juga tidak terlepas dari proses difusi yang terjadi. Mengingat ATBMTT juga merupakan alat inovasi baru yang hadir di tengah-tengah masyarakat khususnya penenun Pandai Sikek. Dari hasil penelitian yang dilakukan maka penyebab kondisi itu terjadi adalah mindset tradisionalisme yang dimiliki penemu ATBMTT serta kerumitan dan keterbatasan ATBMTT.

Ketiga, menenun merupakan keterampilan sakral dan jati diri orang Pandai Sikek. Terlepas dari kondisi alat dan pertimbangan ekonomi, pertimbangan sosial budaya turut mempengaruhi penenun untuk tidak mengadopsi ATBM atau pun ATBMTT. Pertimbangan sosial budaya tersebut tidak terlepas dari fungsi dan kegunaan songket Pandai Sikek sebagai benda wajib dalam prosesi sakral, seperti pengangkatan pangulu, pernikahan, turun mandi, kematian, serta proses batagak rumah. Sebuah keganjilan jika orang Pandai Sikek khususnya perempuan tidak pandai menenun. Hal tersebut juga diperkuat dengan pepatah kato nan ampek ( tahu jotakok baniah, tahu jo suduik kampie, tahu jo liang karok, dan tahu jo atah bakunyah).

\section{Daftar Pustaka}

Achjadi, Judi. Pakaian Daerah Wanita Indonesia Indonesian Women's Costumes. Djambaran.

A. Haviland, William. (1985). Antropology $4^{\text {th }}$ Edition. Jakarta: Erlangga.

Amir MS. (2011). Adat Minangkabau Pola dan Tujuan Hidup Orang Minangkabau. Jakarta: Citra Harta Prima.

Arifin, Bustanul, dkk. (2012). Manajemen Suku. Jakarta: Solok Saiyo Sakato (S3).

Anwar, Zaiful. (1992). Upacara Turun Mandi Anak Secara Tradisional Minangkabau di Daerah Sumatera Barat. Departemen Pendidikan dan Kebudayaan.

Bungin, Burhan. (2006). Sosiologi Komunikasi: Teori Paradigma, dan Diskursus Teknologi Komunikasi di Masyaralat. Jakarta: Kencana.

Dobbin, Christine. (2008). Islamic Revivalism in a Changing Peasant Economy, Centran Sumatera 1784-1847. London: Curzon Pers.

Dhavida, Usria. (1998). Kain Songket Pandai Sikek. Padang: Proyek Pembinan Permusiuman Sumatera Barat.

---------. (2002). Upacara Adat Perkawinan di Kenagarian Koto Barapak Kecamatan Bayang Kabupaten Tanah Datar. Padang: bagian kegiatan pengembangan museum.

Forshee, Jill. (2006). Culture and Costoms of Indonesia. United States of America: Greenwood Press.

Hanafi, Abdillah. (1987). Memasyarakatkan Ide-ide Baru. Surabaya: Usaha Nasional.

Ibrahim, Anwar. (1984). Arti lambang dan fungsi tata rias pengantin dalam menanamkan nilai-nilai budaya provinsi sumatera barat. Dapartemen Pendidikan dan Kebudayaan.

Jurnal Socins: Journal of Sociology Research and Education Vol. 5, No.1, Th. 2018 
(1998). Pakaian Adat Tradisonal Daerah Sumetara Barat. Dapartemen Pendidikan dan Kebudayaan.

Ibrahim, Dt. Sanggoeno Diradjo. (2009). Tambo Alam Minangkabau, Tatanan Adat Warisan Nenek Moyang Orang Minang. Bukittinggi: Kristal Multimedia.

Kahn, Joel's. (1993). Constituthing the Minangkabau: Peasants, Culture, and Modernity in Colonial Indonesia . Oxford, UK: Berg Publishers.

Lauer, Robert. (1993). Perspektif Tentang Perubahan Sosial. Jakarta: Rineka Cipta.

Moleong, Lexy J. (2013). Metode Penelitian Kualitatif Edisi Revisi. Bandung: PT. Remaja Rosdakarya.

Sjarifoedin, Amir. (2011). Minangkabau Dari Dinasti Iskandar Zulkarnain Sampai Tuanku Imam Bonjol. Jakarta: PT. Gria Media Prima.

Sihbudi, R \& Nurhasim, M. (2001). Kerusuhan Sosial di Indonesia, Studi Kasus Kupang, Mataram dan Sambas. Jakarta : Grasindo.

Setiadi, Elly \& Usman Kolip. (2011). Pengantar Sosiologi Pemahaman Fakta dan Gejala Permasalahan Sosial:Teori, Aplikasi, dan Pemecahannya. Jakarta: Kencana. 